\title{
Examination of Preservice Teachers' Perceptions about Evolution Course
}

\author{
Zeha Yakar ${ }^{1, *}$ \\ ${ }^{1}$ Faculty of Education, Pamukkale University, Denizli, Turkey \\ *Correspondence: Faculty of Education, Pamukkale University, Denizli, Turkey. Tel: 90-258-296-1178. E-mail: \\ zyakar@pau.edu.tr
}

Received: January 24, 2020

Accepted: February 4, $2020 \quad$ Online Published: February 19, 2020

doi:10.5430/wje.v10n1p102

URL: https://doi.org/10.5430/wje.v10n1p102

\begin{abstract}
This is a study that explored 117 Turkish preservice science teachers' views about evolution course. The data for the study were collected through a questionnaire that has open-ended questions. The preservice science teachers answered the questions by filling out the questionnaire at the beginning and end of the evolution course. Most of the preservice science teachers stated that they had many misconceptions and prejudice about the theory of evolution before taking this course. However, after taking it, they noticed that the theory of evolution is not only about human ancestors but it is related to all living things. Another important result of this study, as they have stated many times, evolution was a very interesting theory for them, and since meeting the theory, they had been asking too many questions to themselves and wondering and doing lots of research on it. All these results of this study show that evolution course was successful in engaging the preservice science teachers in evolution and enhancing their learning.
\end{abstract}

Keywords: views about evolution theory, teaching evolution, preservice science teachers, science teacher education program

\section{Introduction}

Science helps us to address general concerns of population. Scientific principles have continued to be applied to address issues, concerns, and problems that people face in the day-to-day aspects of life. Therefore, science is an important subject for public and all levels of education. However, many studies have shown that many students, and even teachers, possess an inadequate understanding of science and its nature. This situation might be harmful "particularly in societies where citizens have a voice in science funding decisions, evaluating policy matters and weighting scientific evidence provided in legal proceeding[s]. At the foundation of many illogical decisions and unreasonable positions are misunderstandings of the character of science (McComas, Almazroa, and Clough, 1998, p. 511)". Thus, many science curricula now aim to help learners attain an adequate understanding of the nature of science, which is a critical component for scientific literacy (American Association for the Advancement of Science, 1990). Scientific literacy has been described as (NRC, 1996, 22):

Scientific literacy means that a person can ask, or determine answers to questions derived from curiosity about everyday experiences. It means that a person has the ability to describe, explain, and predict natural phenomena. Scientific literacy entails being able to read with understanding articles about science in the popular press and to engage in social conversations about the validity of the conclusions. Scientific literacy implies that a person can identify scientific issues underlying national and local decisions and express positions that are scientifically and technologically informed. A scientifically literate citizen should be able to evaluate the quality of scientific information on the basis of its sources and the methods used to generate it. Scientific literacy also implies the capacity to pose and evaluate arguments based on evidence and to apply conclusions from such arguments appropriately.

When people are scientifically literate, they "should develop an understanding of the concepts, principles, theories, and processes of science, and an awareness of the complex relationships between science, technology, and society...[and] more important[ly]...an understanding of the nature of science" (Abd-El-Khalick and BouJaoude, 
1997, p. 673). Science educators are responsible for teaching the best knowledge in all fields of science and to identify and correct student misconceptions (NRC, 1996). If science teachers have the necessary skills and knowledge about the nature of science, their students' understanding of science and nature of it will improve.

A lot of literature states that teaching evolution is an effective way to improve students' understanding of the nature of science (NRC, 1996; NAS, 1998; Bybee, 2001, 2004; Berkman \& Plutzer, 2012). While teaching evolution, it is possible to see the relationship between the scientific processes and the structure and development of a theory (the similarities among living things, the diversity of life, and many features of the physical world we inhabit). Teaching evolution has a great practical application for students. Theory of evolution, either directly or indirectly, has made a lot of contributions to the society. For instance, we can find answers to the question why many human pathogens have been developing resistance to formerly effective drugs and we can suggest ways of confronting this increasingly serious problem through understanding evolution. Evolutionary biology has also contributed in many important agricultural advances by explaining how organisms are related, which is a very important consideration in any crop management system. For example, understanding the evolution of insects' resistance to pesticides allows us to develop the use of pesticides in a more effective way. The other important point of the understanding of evolution is that, it has been essential in finding and using natural resources like fossil fuels, and it will be indispensable as human societies strive to establish sustainable relationships with the natural environment (NAS, 1998; Bybee, 2004).

Apparently, teaching of evolution is a good way to teach students how science is performed and how we have obtained current body of scientific knowledge. There are too many researches that have addressed teachers' attitudes concerning evolution (Weld and McNew, 1999; Rutledge and Mitchell, 2002; Moore, 2007; Moore and Cotner, 2009; Berkman and Plutzer, 2012; Asghar, 2013). However, teaching the theory of evolution to students can be quite challenging because of the teachers' lack of understanding of the basic nature of science and the theory of evolution. This lack is characterized by quotes both from lay people and science teachers with phrases like: "Evolution is far from being proven;" "Teach evolution as a theory, not a fact;" and "Evolution is just a theory" (Bybee, 2001). Apparently, these statements reveal that the public understands a scientific theory as a guess, a hypothesis, or lack of understanding. One study has shown that the non-biology major college students' lacking the understanding of both the nature of science and the theory of evolution correlated with a low acceptance rate of the theory of evolution. Teacher acceptance of evolutionary theory is significantly related to teacher understanding of the theory of evolution and the nature of science and it affects students' understanding of both concepts (Bishop and Anderson, 1990). Therefore, science teachers are the key factors in increasing students' understanding of the nature of science and the theory of evolution. Many researches have shown that the more teachers' acceptance and knowledge of evolution increased, the more time they spent on teaching of evolution (Rutledge and Warden, 2000; Rutledge and Mitchell, 2002, Griffith and Brem, 2004; Berkman and Plutzer, 2012; Asghar, 2013). One of these studies stated that the teaching of the theory of evolution could be more effective, if teachers possessed the most up-to-date information and access to richer lesson planning including science and personal experience (Griffith and Brem, 2004). Thus, teacher education programs have an important role on improving preservice science teachers' understanding of nature of science and theory of evolution. For this reason, evolution was added as a course and begun to be taught in 2006-2007 academic year at all science teacher education programs in Turkey. However, there are few researches on the preservice science teachers' views on the evolution course. Hence, the purpose of this study was to determine Turkish preservice science teachers' views on the Evolution Course.

\section{Methodology of Research}

The present study was simple descriptive survey research in nature (Straussand \& Corbin, 1990) because it focused on the meanings that participants referred to emphasize their view about the benefits of the Evolution Course and their views about importance and necessity of the course.

\subsection{Participants}

The participants are preservice science teachers at a faculty of education in a state university in one of the cities located on the west of Turkey. Purposive sampling is used to select the participants. In purposive sampling, it is assumed that the person chosen possesses the necessary information about the target population (Franklen and Wallen, 1996). This study was conducted with $1174^{\text {th }}$ grade volunteering preservice science teachers. These preservice science teachers have already completed basic science courses, science laboratory courses, nature and history of science course, and methods of science teaching courses. 


\subsection{Context of the Study: Evolution Course}

Evolution course was a two credit/hours required course. The weekly classes were held in two-hour blocks throughout a semester. The course aimed to help preservice science teachers to develop (a) theoretical framework about the Theory of Evolution, (b) deeper understanding of some science content areas such as mutation, genetics of the population, modification, variation and natural selection, and (c) understanding of nature of science.

The first sessions of the course were spent to establish ground rules of tolerance and respect within the course; all preservice science teachers were encouraged to tell their opinions freely, and were reassured that no one would be criticized (or graded negatively) for expressing his/her opinion. In the first session, how the terms such as "fact", "hypothesis", "theory", and "law" are used in science was discussed. For example, "theory" is a well-tested, repeatedly confirmed explanation rather than a guess. Because of the students' educational background and their understanding of evolution, the course was designed to bring all preservice science teachers to a basic understanding of what nature of science and evolution are, and how science works. During the course, many videos on the process of evolution and natural selection were watched. These videos were The Tree of Life- BBC Documentary, Great Migrations- National Geographic, Food Inc.- American Documentary, Home- TV Series Planet Earth. "The Tree of Life" is a documentary about theory of evolution through natural selection. It is possible to see natural selection, variation, mutation and adaptation on "Great Migration" documentary. "Food Inc." is a documentary showing artificial evolution. "Home" is a documentary that shows the relationship between global warming and evolution.

After watching these videos, preservice science teachers were encouraged to discuss and express their opinions about it. During the discussions, preservice teachers expressed their initial reactions to the documentaries and the course time was spent to resolve any points of confusion concerning the videos such as theory of evolution, natural selection, artificial selection, mutation, adaptation, global warming and evolution. In general, during the whole semester of this course, such as class discussion, questioning, presentation, videos were commonly used as teaching methods.

\subsection{Data Collection}

The data were collected at the beginning and at the end of the fall semester of 2016-2017 academic years from preservice science teachers through an open-ended questionnaire. A questionnaire was used to collect data from the participants of the study. The questionnaire has three open-ended questions without any reference to any particular scientific context but it rather includes explicit question items. As first, in order to determine for prior knowledge of preservice science teachers about the theory of Evolution, the following question "What do you know about the theory of Evolution?" was asked them. Through this question, preservice science teachers' prior knowledge of evolution from the television programs, some magazine news, and their science courses at high school tried to determine and also determine their prejudice about the theory of evolution. And then at the beginning and at the end of the course, participants wrote their thinking about the following two questions that were prepared by the researcher in accordance with the research questions of this study: "What do you think about benefits of the evolution course?" and "What do you think about necessity of Evolution Course?" Through these questions assessed the same issues; they were asked in order to get access to preservice teachers' views on the importance of evolution course in science teacher education program. A study of Leach (1996) claims that asking explicit questions about science has many disadvantages such as the problem of reflecting the actual thoughts and capturing the same meaning about issues related to science. On the other hand, thinking of the participants as the science teachers' of the future, they are expected to have basic explanation skills related to their experience. Therefore, they were asked to give explicit descriptions and make choices by indicating the reasons behind.

\subsection{Data Analysis}

This study was focused on general and reflect the intention of finding out the views of preservice science teachers about the importance of evolution teaching, the descriptive approach was used. The preservice science teachers answered the questions by filling out the question form at the beginning and at the end of seventh semester when they enrolled in the evolution course. The analysis of preservice science teachers' written responses was coding according to their responses showing their views about the importance of the evolution course. All of the responses for each question were analyzed in turns. In the analysis, the structures towards particular meanings, concepts and relations were tried to be figured out where it is necessary to establish these structures with the codes identifying them (Büyüköztürk, Kılıç-Çakmak, Akgün, Karadeniz, and Demirel, 2008). Therefore, the answers were examined to draw comparisons and distinctions according to their meanings in order to identify the coding.

Firstly, preservice science teachers' written responses were examined by the researchers independently. Next, the researchers came together and decided the final form of the coding. Then, each researcher worked individually in 
order to group these coding. These coding were compared and the final form of the coding was constructed. An inter-rater reliability for this questionnaire was tested by two science education experts. Each coder separately analyzed the data that was randomly selected from the question forms. Pearson correlation was used to determine the inter-rater reliability and the value $r$ was found to be 0.92 . This value indicates the high level of agreement.

\section{Results of Research}

Results are presented in three sections. In the first section, responses of the preservice science teachers to research question that addressed their prior knowledge about evolution are presented. The second section presents the results of analyses of the preservice science teachers' responses to the item that addressed their thinking about the benefits of the course at the beginning and at the end of the course. In the last section, responses of the preservice science teachers on the importance of the evolution course at teacher education programs at the beginning and at the end of the course are presented. Results of the participants' responses are presented as frequencies and percentages.

\subsection{The Knowledge before Taking the Course of Evolution}

Preservice science teachers' knowledge on evolution before taking the evolution course was presented with codes in Table 1.

Table 1. Prior Knowledge about Evolution Theory before Taking the Evolution Course

\begin{tabular}{lcc}
\hline Prior Knowledge before Taking the Evolution Course & Frequency (f) & Percentage (\%) \\
\hline Evolution means human beings have evolved from monkeys. & 93 & 79 \\
Not enough knowledge about the theory. & 24 & 20 \\
- However I have some prejudice about the theory. & 17 & 14 \\
Darwin is the founder of the theory of evolution. & 31 & 26 \\
- Just a collapsed theory because of lack of evidence. & 5 & 8 \\
- Darwin did not believe in any religion. & 9 & 4 \\
- Mentioned about mutation, variation, speciation, natural selection. & 7 & 6 \\
- Living things have a single ancestor. & & \\
\hline
\end{tabular}

*Preservice science teachers stated more than one statement

It can be seen on the table that according to most of the preservice science teachers (79\%), evolution means humans' being the developed forms of apes or monkeys. Besides $20 \%$ of participants thought that they did not have enough knowledge about the theory; $14 \%$ of them accepted that they have some prejudice about it because of some television programs, some anti-evolution books, articles and some web sites. Apparently, many preservice science teachers held the misconception of Darwin's idea as they thought him to have said that humans directly descended from modern apes so they rejected the theory of evolution based on this idea. While $26 \%$ of preservice science teachers stated that Darwin was the founder of evolution theory, $8 \%$ of them agreed that evolution was scientifically wrong and/or that it was not based on evidence, that evolution was designated as a theory because of a lack of evidence, and that evolution was both a fact and a theory and it had not evolved into a law yet. Interestingly, $4 \%$ of them stated that Darwin did not have any religion and they stated that if people believed in evolution, they would be atheists. Because of these reasons, most of them thought that it is an absurd theory and they did not search or read about it till taking evolution course at the teacher education program. Just a small portion of preservice science teachers (8\%) mentioned mutation, variation, speciation, and natural selection. And just $6 \%$ of the participants stated that evolution meant that living things had a single ancestor.

\subsection{Views about the Benefits of the Evolution Course}

Before and after Evolution Course, preservice science teachers were asked views about the benefits of the Evolution Course and their views were presented with codes in Table 2. 
Table 2. Views about Benefits of the Evolution Course

\begin{tabular}{|c|c|c|c|c|}
\hline & Pre & Test & Post & Test \\
\hline What do you think about benefits of the evolution course? & $\begin{array}{l}\text { Frequency } \\
\text { (f) }\end{array}$ & $\begin{array}{l}\text { Percentage } \\
(\%)\end{array}$ & $\begin{array}{l}\text { Frequency } \\
\text { (f) }\end{array}$ & $\begin{array}{l}\text { Percentage } \\
(\%)\end{array}$ \\
\hline Acquire knowledge about the theory. & 94 & 80 & 96 & 81 \\
\hline Overcome the misconceptions and prejudice & 4 & 3 & 49 & 41 \\
\hline Learn questioning and doing research & 9 & 8 & 36 & 30 \\
\hline Gain different perspectives & 13 & 11 & 30 & 25 \\
\hline Learn the process of science & 10 & 8 & 20 & 17 \\
\hline $\begin{array}{l}\text { Learned being respectful other thoughts and to keep out } \\
\text { from being biased }\end{array}$ & - & - & 32 & 27 \\
\hline $\begin{array}{l}\text { Recognized the scientists, especially Darwin, and their } \\
\text { work }\end{array}$ & - & - & 23 & 19 \\
\hline Learned to separate scientific and non-scientific knowledge & - & - & 12 & 10 \\
\hline
\end{tabular}

*Preservice science teachers stated more than one statement.

When examining Table 2, after taking the evolution course at the teacher education program, preservice science teachers stated many points as benefits of this course more than their expectations. For example, $80 \%$ of them expected to learn reliable information about the theory from this course and then after taking the course $81 \%$ of them stated that they had learned the reliable knowledge about the theory through this course. Besides them, while just only $3 \%$ of them wanted to correct misconception and overcome their prejudice about the theory, $41 \%$ of the participants emphasized that they had had a chance to correct their misconceptions about evolution after the course. They thought that class discussion about the topics of evolution had been very effective to correct their misconceptions and prejudices.

Another important result is that before taking course just $8 \%$ of preservice science teachers expect to learn questioning and doing research, however, after taking the course $30 \%$ of them responded that they had learned questioning and doing research during the course. On the other hand, while $11 \%$ of preservice science teachers expect to gain different perspective about theory of Evolution through the Evolution Course, $25 \%$ of them stated that they had gained different perspectives through the evolution class after course. Another statement before taking class is that $8 \%$ of them expected to learn the process of science; however, after taking the course, $17 \%$ of them stated that they learned the process of science much better through the evolution course. After watching videos and joining the class discussions on some topics of evolution such as mutation, variation, and natural selection, the participants stated that they wondered more about the theory of evolution and they tried to find out answers about the questions in their minds through different resources. Therefore, they did lots of research in addition to the course assignments.

Results showed that after evolution course preservice science teachers stated much more statement. For instance, one of the other important statements is that $27 \%$ of the participants stated that they had learned to keep out from being biased towards the evolution theory and science during the class discussion. They also stated that it was important listen to others and being respectful to other thoughts. Another important statement is $10 \%$ of the participants stated that they used internet to access some information about evolution, however, they thought that there were too many unreliable web sites. They claimed that it was important to separate scientific knowledge and non-scientific knowledge and they stated that through this course, they learned what scientific knowledge is and how they could separate it from the non-scientific knowledge. Before taking this course, most of the participants did not know anything especially about Charles Darwin, for example, how much of his time he had spent for observation, collecting data, preparing collection, thinking about his theory and writing his analysis. After taking this course $19 \%$ of the preservice science teachers emphasized that they had a chance to recognize many scientists, especially Darwin, and their works very closely and they stated that now they respect scientists and their works more.

\subsection{Views about Necessity of Evolution Course}

At the beginning and at the end of Evolution Course, preservice science teachers were asked their thinking about the necessity of Evolution Course and their views about it were presented with codes in Table 3. 
Table 3. Thinking about the Necessity of Evolution Course

\begin{tabular}{lcccc}
\hline What do you think about the necessity of Evolution Course? & Pre & Test & Post & Test \\
\cline { 2 - 5 } & $\begin{array}{l}\text { Frequency } \\
\text { (f) }\end{array}$ & $\begin{array}{l}\text { Percentage } \\
\text { (\%) }\end{array}$ & $\begin{array}{l}\text { Frequency } \\
\text { (f) }\end{array}$ & $\begin{array}{l}\text { Percentage } \\
(\%)\end{array}$ \\
\hline Yes, it is necessary to teach evolution course. & $\mathbf{9 9}$ & $\mathbf{8 4}$ & $\mathbf{1 1 4}$ & $\mathbf{9 7}$ \\
- Correct misconceptions and prejudice & 9 & 8 & 83 & 70 \\
- Learn theory as a future science teacher & 48 & 41 & 60 & 51 \\
- Recognize the nature of science and process of science very closely & 9 & 8 & 6 & 37 \\
- Learn questioning, doing research and gain different perspective & 10 & 8 & -37 & 8 \\
- Be common sense to scientists and their work & - & - & $\mathbf{1}$ & $\mathbf{1}$ \\
No, we should not teach evolution course. & $\mathbf{2}$ & $\mathbf{2}$ & 2 & 1 \\
- Lack of evidence. Evolution is just a theory. & 2 & $\mathbf{1}$ & $\mathbf{3}$ \\
Not sure about teaching evolution course. & $\mathbf{1 7}$ & $\mathbf{1 4}$ & $\mathbf{3}$ \\
\hline
\end{tabular}

*Preservice science teachers stated more than one statement.

It can be seen in Table 3 that while beginning of the course $84 \%$ of the preservice science teachers thought that teaching evolution at the teacher education programs is necessary; this percent was increase to $97 \%$ at the end of the course. Only According 70\% of the preservice science teachers, teaching evolution is very important since they had a chance to correct their misconceptions and their prejudices about the theory of evolution thanks to the evolution course. In addition, just only $8 \%$ of preservice science teachers before taking this course were thinking that teaching evolution course is necessary in terms of learning questioning, doing research and gaining different perspective, however after taking this course this percent increase to $31 \%$ and they stated that their interest about evolution increased through this course, they asked too many questions about the theory and they did many research to find answer their questions and in this way they were able to gain different perspectives through this course. $41 \%$ of preservice science teachers believed that learning evolution was necessary as future teachers at the beginning of course. This percent was increased $51 \%$ at the end of the course. They thought that theory of evolution is a popular theory and they had to teach evolution to their students. The more they learn on evolution, the better they would teach the theory, and they would be able to answer their students' questions. $8 \%$ of the participants responded that through this course, students would recognize the scientists and their work closely. And they would develop good attitudes and be common sense to scientists and their work.

Only one of the participants thought that theory of evolution should not be taught at teacher education programs, because of lack of evidence and this participant stated that evolution was just a theory, it had not become a law. However, apparently, this preservice science teacher has misconceptions about what theory and law are. Because this participant believed that theories become laws depending on the availability of the supporting evidence, however, we know that theories and laws are different constructs. Another important result of this study, $14 \%$ of preservice science teachers responded that they could not decide teaching evolution at teacher education program was necessary or not to show without any reason before taking course. On the other hand, at the end of this course the percentage of them decreased to $2 \%$ and they stated that two reasons. First reason, they thought that evolution course was only a two hours in a week and according to them, time was not enough to teach this theory. Another reason they stated that; it was hard to separate scientific thought and beliefs. If the instructor could not be successful in separating them, understanding evolution might not be achieved.

\section{Conclusion and Discussion}

Considering teaching of evolution course at science teacher education programs, the primary goals of this study were to determine that before taking the evolution course, Turkish preservice science teachers' views on the evolution course through their written answers based on their prior knowledge on the theory of evolution; to determine their views on the benefits of the course of evolution, and to determine their views on the importance of teaching evolution. According to the results presented above, before taking this course, most of the preservice science teachers had misunderstandings on the basic concepts related to evolution (e g. ancestor, humans evolving from modern apes) that may have led them to reject evolution and they may prefer to accept the religious explanations. This study results indicated that many students misunderstood the notion of common descent or they did not have enough knowledge on the theory. However, although they did not have enough knowledge, they had some prejudice about the theory because of, most probably, their religious beliefs and cultural background. 
Their written answers showed that before taking this course, some of them thought evolution was a collapsing theory because of lack of sufficient evidence and thus, it was not 'correct'. On the other hand, they think that laws are "stable", and supported with sufficient evidence. This inadequate understanding of the nature of theories led many preservice science teachers to conclude that the "theory of evolution" was not scientifically supported and that more evidence was needed to change its status from being a theory to a law. This result is very similar to the results reported by BouJaoude, Wiles, Asghar, and Alters (2011). However, after taking this course, they considered that their thoughts on the theory of evolution had almost totally changed. They noticed that the theory of evolution was not only about human ancestors. It is about all living things and it is in our life.

Another important result of this study is, during the course, preservice science teachers did many researches about the theory of evolution. In this way, they acquired a lot of information about the theory and they learned more. Most of them thought that they overcame their misconceptions and their prejudice through their research. Actually, as an educator, we know that it is hard to change misconceptions and it takes too much time to do so. Even though this course may not be enough to overcome all their misconceptions and prejudice, the preservice science teachers had a chance to realize their prejudice and misconceptions on the theory of evolution through this course. Thus, almost all preservice science teachers believe that teaching evolution is very important and necessary.

The other important result of this study is; they had stated for many times that evolution is a very interesting theory for them, and since meeting the theory, they had been asking too many questions to themselves and wondered about it. And again, they stated that even just to find answers to their questions, they were doing too many researches such as searching a lot of web sites and reading many articles, books and news. According their views on the benefits of the course, they learned asking questions to themselves and doing research through this course and they realized the differences between scientific and unscientific information through their research. Additionally, some preservice science teachers stated that they gained different perspectives and understood the importance of being respectful to other thoughts during the course. Frankly, it was not the purpose of this course to instruct the preservice science teachers to believe in evolution or to reject their religious believes. One of the main purposes of this course was to instruct the preservice science teachers to begin to question the nature of science. In this respect, it is possible to say that the process of the course was very successful.

Considering all these learning outcomes of evolution course, teaching evolution is very worthy and important to improve the understanding the nature of science and being a scientifically literate person. These results of this study showed that evolution course was successful to improve understanding about nature of science of preservice science teachers and enhancing their learning. In conclusion, preservice science teachers are more likely to develop appropriate understandings of evolution, if they are taught about the nature of scientific facts, theories, and evidence and are given the opportunity to discuss their values and beliefs in relation to scientific knowledge in non-threatening environments. It is the best way to teach the nature of science integrated with teaching evolution.

One of the important goals in the newly improved elementary school science curricula in Turkey as in many countries is to train scientifically literate individuals for a healthy and developing society. It is an undeniable fact that we need primarily qualified science teachers, who have a great role in shaping the students' views of nature of science, in order to produce scientifically literate students. Therefore, science teachers must possess contemporary views about the evolution theory and they should keep in mind that the theory of evolution is a good tool for teaching the nature of science at all levels. In order to achieve a scientifically literate society, science teacher educators and science teachers should work hard.

\section{References}

Abd-El-Khalic, F., \& BouJaude, S. (1997). An exploratory study of the knowledge base for sciene teaching. Journal of Research in Science Teaching, 673-699. https://doi.org/10.1002/(SICI)1098-2736(199709)34:7<673::AID-TEA2>3.0.CO;2-J

American Association for the Advancement of Science. (1990). Science for all Americans. Washington DC: Oxford University Press

Asghar, A. (2013). Canadian and Pakistani Muslim teachers' perceptions of evolutionary science and evolution education. Evolution: Education and Outreach, 6(10), 1-12. https://doi.org/10.1186/1936-6434-6-10

Berkman, M., \& Plutzer, E. (2012). An evolving controversy: The struggle to teach science in science classes. American Educator, 36(2), 12-40.

Bishop, B., \& Anderson, C. (1990). Student conceptions of natural selection and its role in evolution. Journal of 
Research in Science Teaching, 27, 415-427. https://doi.org/10.1002/tea.3660270503

BouJaoude, S., Wiles, J. R., Asghar, A., \& Alters, B. (2011). Muslim Egyptian and Lebanese students' conceptions of biological evolution. Science and Education, 20, 895-915. https://doi.org/10.1007/s11191-011-9345-4

Büyüköztürk, Ş., Kılıç Çakmak, E., Akgün, O. E., Karadeniz, Ş., \& Demirel, F. (2008). Bilimsel araştırma yöntemleri [Scientific Research Methods]. Ankara: Pegem Yayınları.

Bybee, R. (2001). Teaching about evolution: Old controversy, new challenges. Bioscience, 51(4), 309-312. https://doi.org/10.1641/0006-3568(2001)051[0309:TAEOCN]2.0.CO;2

Bybee, R. (2004). Evolution in perspective: The science teacher's compendium. Arlington, VA: NSTA Press.

Franklen, J. R., \& Wallen, N. E. (1996). How to design and evaluate research in education (3rd ed.). Mcgraw-Hill, Inc.

Griffith, A. J., \& Brem, K. S. (2004). Teaching evolutionary biology: Pressures, stress, and coping. Journal of Research in Science Teaching, 41(8), 791-809. https://doi.org/10.1002/tea.20027

Leach, J. (1996). Students' understanding of nature of science. In: G. Welford, J. Osbourne, P. Scott (Eds.), Research in Science Education in Europe. Washington DC:Routledge falmer.

McComas, W., Clough, M., \& Almazroa, H. (1998). The role and character of the nature of science in science education. In McComas, W. (Ed.), The nature of science in science education: Rationales and strategies (p. 3-39). Dordrecht: Kluwer Academic. https://doi.org/10.1007/0-306-47215-5_1

Mertens, D. M. (1998). Research methods in education and psychology: Integrating diversity with qualitative and quantitative approaches. London: Sage.

Moore, R. (2007). What are students taught about evolution? McGill Journal of Education, 42(2), 177-187.

Moore, R., \& Cotner, S. (2009) The creationist down the hall: Does it matter when teachers teach creationism? BioScience, 59, 429-435. https://doi.org/10.1525/bio.2009.59.5.10

National Academy of Sciences. (1998). Teaching about evolution and the nature of science. Washington, DC: National Academy Press.

National Research Council. (1996). National Science Education Standards. Washington, DC: National Academy Press.

Rutledge, M. L., \& Mitchell, M. A. (2002). High school biology teacher' knowledge structures, acceptance and teaching of evolution. The American Biology Teacher, 64(1), 21-28. https://doi.org/10.1662/0002-7685(2002)064[0021:HSBTKS]2.0.CO;2

Rutledge, M., \& Warden, M. (2000). Evolutionary theory, the nature of science \& high school biology teachers: Critical relationships. The American Biology Teacher, 62(1), 123-31. http://dx.doi.org/10.1662/0002-7685(2000)062[0023:ETTNOS]2.0.CO;2

Strauss, K. A., \& Corbin, J. (1990). Basics of qualitative research: Grounded theory procedures and techniques. London: Sage Publications.

Weld, J., \& McNew, J. C. (1999). Attitudes toward evolution. In Bybee, R.W. (Ed.), Evolution in Perspective (p. 49-55). Arlington, Virginia: NSTA press. 